\title{
The Role of Big Data in Political Campaigns (Case Study of Jakarta Special Region Province)
}

\author{
Irwansyah $^{1}$,Woko Setiawan ${ }^{2}$ Evvy Silalahi ${ }^{3}$ \\ \{dr.irwansyah.ma@gmail.com ${ }^{1}$, evyta.pinisievents@gmail.com ${ }^{2}$, evyta21@ gmail.com ${ }^{3}$ \} \\ Lecturer of Communication studies, Universitas Indonesia Jln. Salemba Raya, Jakarta $10440^{1}$, \\ Direktur Teknologi Informasi, PT.Idemuda Digital Indonesia, Cipedak Jakarta Selatan ${ }^{2}$, \\ Lecturer of STIKOM InterStudi, Jl.Wijaya II No.62, RW.1, Melawai, Jakarta Selatan $12160^{3}$
}

\begin{abstract}
This research is about the role of Big Data in Indonesia in political campaigns. The method used is a mix method that is quantitatively by means of computing with a Big Data based application called BitWafl Media Analytic. Then using a qualitative method by means of narration in which with this method the data is drawn and explored thematically then narrated. Quantitative data collection by Data Mining represents the discovery of useful patterns or trends through a number of Big Data while qualitatively with open interviews.The recommendations of the results of this study are that big data technology has a significant role in political campaigns, but the technology still requires an important role for humans to package campaign messages or as operators.
\end{abstract}

Keywords: Big data, political campaigns, political communication, election. 


\section{Introduction}

The internet is instrumental in searching and exchanging information. The use of campaign information from the internet has profound effects among the youngest groups (ages 18-23). When used for information search and exchange, the internet will likely increase political knowledge and other types of knowledge [1]. Currently, Indonesia ranks 4th in the growth of internet usage in the world with growth until January 2019 while in the first rank was India, this illus trates that the transformation of analog culture to digital has shifted rapidly [2], so that Indonesia with the penetration of internet users in the world with penetration internet users reach 56\% from 2019. Although internet speed infras tructure in Indonesia was still ranked 41st in the world, with an average speed of $15.5 \mathrm{Mbps}$, it is not directly proportional to the average time spent using the internet in Indonesia, becau se Indonesia ranks fifth in the world. The enthusiasm for using digital media by the public can be reflected through the use of the internet through desktops and laptops, reaching an average of 8 hours 36 minutes perday. The description of the use of social media through mobile phones, the penetration of socialmedia use through mobile phones in Indonesia was ranked 31th in the world, with the number reaching $48 \%$ [2].

The presence of Big Data technology is beneficial in the field of business and political marketing. Big Data is us eful not only analyzing consumer behav iour as a busines s prospect but als o analyzing consumer behaviour as a campaign target in political marketing through the behaviour of people as internet users [3]. The use of Big Data in the initial political campaign was popularly used in the election of the US President. The US President Uses Big Data and Network Analysis by Saatviga Sudhahar, Giuseppe A Veltri and Nello Cristianini from the Department of Computer Science, University of Bristol, Bristol, England and the Department of Media and Communication, University of Leicester, Leicester, England. The discussion of Big Data's automatic breakdown of 130,213 news articles about the US presidential election in 2012 produced a network formed by key political actors and issues, which were linked to support and opposition relations. In the discussion of this study, it is explained that all countries run a democratic system, so elections are an arena of exploration and symbolic mobilization by using s trategic concepts through words and visuals to influence public opinion on candidates [4].

With the accumulation of many data from various sources in countries that run democracy well and progressively, it has created a challenge that is very difficult for researchers to deal with. So that overall analysis is sometimes not an option, the researchers focus more on content analys is both manually and automatically. Moreover, it allows researchers to identify campaign problems with the most prominent is sues in each candidate's campaign, for example [5]. 
The purpose of the overall political campaign is to maximize the probability of victory. For this reas on, every as pect of the campaign is evaluated by the numb er of votes that will be produced, what activities are carried out, and how much they will cost. In conducting a cost benefit analysis, the campaign requires accurate predictions of voter preferences, the behaviour they expect, and their response to campaign outreach. Data obtained from issues in online media and social media can be a reference to see one's political behaviour. Not only for businesspurposes, butBig Data should have significant benefits in politics. How to see voter behaviour towards the sentiment of existing issues and relate them to the electability of candidates and see the challenges and opportunities of these Over the past six years, campaigns have increasingly relied on analyzing extensive and detailed data to create the neces sary predictions. Although the adoption of this new analytical method does not radically change how the campaign operates, better efficiency provides a smart campaign for competitive data excellence. Thus, many political parties involved in the competition to take advantage of the growing data to get votes [6].

According to previous research of Burt [7] the description of the opportunities and utilization of Big Data in the international community, especially the United States in the world of politics, and how President Obama used Big Data technology facilities well to defeat other candidates and Obama won the election twice. In other side , research of Bennet [8] analyzes the coverage of big data in mas s media, by combining and combining the methods of linguistic automation and network analys is. Network representation and mapping from all news media, both online and offline, which presents the campaign is the bas is for network analys is. The role of internet and big data in political campaign is interesting to study in Indonesia. Ideally, if in Indonesia the role and function of Big Data have been used well to eat the candidates who fight in politicalcampaigns can carry out political marketing strategies to achieve victory. Baseon previous res earch and the data of using internet in Indonesia, writers interest to research about role of big data in political campaign especially in DKI Jakarta election 2017.

Phenomenon results of the survey published in the mass media showed that the level of satisfaction of the citizens of DKI towards Ahok Djarot's performance was more than $60 \%$ [9] [10] which should have a high chance of victory and logically should the Ahok-Djarot pair win the DKI1 \& 2 fight. However, the reality is not the case, the pair lost the second round. Should the Ahok Djarot success teambe able to reduce the is sue that befell Ahok by raising is sues with other themes through the Big Data technology features, such as what programs are already running and communicating with citizens about what people need based on age, and observing the theme - other is sues that can be raised. Then a great interpersonal skill approach to the middle and lower clas ses is likely to help significantly embrace the hearts and voices of the citizens ofDKI. With the existence of Big data technology, it should help map areas that need special attention. According to data of satisfaction citizen of DKI Jakarta above $60 \%$, it should be Ahok Djarot could win the election, but the fact they lost the wining. Base on this fact, the problem of this research is how about the role of big data in political campaign at case study DKI Jakarta governor election 2017. Because of the limitation of data and time, this study only research for second round of election and we also only reach of informan from Anis Sandi team.The purpose of this research is to identify how the role of Big Data Technology in the second Round of the DKI Jakarta governor election Campaign in 2017. This study provides benefits in the form of extracting data extracted through the Bitwafl application tools, how behaviour and public opinion during the second period of the DKI Jakarta governor election campaign period 2017, acoring to previous research from Burt [7] and als o Nickers ons and Rogers [6] that found about advantage of using internet and big data 
to get voters and win the campaign especially in Amerika when President Obama won the general election by using big data.

\section{Literature Review}

\subsection{Political Communication}

Campaigns are part of communication activities [11]. Political campaigns are one of the political communication strategies. Campaigns are part of communication activities (McQuail, 2010). Political campaign is one of political communication strategies. Dan Nimmo's state that political communication as a communication activity based on the consequences (actual or potential) that govern human actions in conflict conditions [12] In other side Michael Schuds on [13] states political communication:

"Any transmission ofmessages that has, or is intended to have, an effect on the distribution or use of power in society or an attitude toward the use power"

\subsection{Political Campaign}

Rogers and Storey [14] define campaigns as a series of planned communications actions with the aim of creating certain effects on a large number of audiences that are carried out sustainably over a period of time. Campaigns can be interpreted as the use of various different communication methods in a coordinated manner within a certain period of time aimed at directing audiences to certain problems and their solutions. Political campaigns are one form of political communication. Political campaigns are a process of a series of political communications between politicalcontestants and voters. Political contestants are political actors. These political actors can be political parties and political candidates. Nimmo further said that, a political communication expert, means that political campaigns are the re-creation and transfer of significant symbols continuous ly through communication [12].

In its development, campaigns in modern politics are influenced by various things. Judith S Trent and Robert V Friedenberg [15] mention there are four factors that influence political campaigns; first, the decline of political parties. Second, financial legislation in the electoral system. Third, the election committee's political policy. Fourth, technological development. Some experts conclude there are variables that influence the form of political campaigns such as, the role of political parties, voter demographics, philosophical questions, economic conditions. In political campaigns, the message channel/ politicalmes sage medium holds control of the delivery of messages to the public, because candidates who want to influence public opinion can controlevery aspect of the message and every presentation or format of the message. The internet provides candidates with a tool to channel information directly to the public. With the development of internet technology today, it allows political marketing to be used in social media. The use of Twitter, Facebook, blogs, websites as direct delivery media to the public is a cheaper and more efficient alternative. Using the internet is considered cheap. Realizing the role and character of this internet is often used even for candidates who lack funds. The internetfunctions to provide a site to these candidates as a means of connecting with voters.

\subsection{Role and Function of Big Data}

Big Data is a term that applies to information that cannot be proces sed or analyzed using traditional tools [16]. Big Data is data that exceeds the capacity process of the existing 
database system capabilities. Data is too large and too fast or not in accordance with the existing database architecture structure. To get the value of the data, it must choose the alternative path to process it [17]. According to Dumbil [16], Big Data is data that exceeds the capacity process of the existing database systemcapabilities. Data is too large and too fast or not in accordance with the existing database architecture structure. To get the value of the data, you mustchoose the alternative path to process it. Data is the "raw material" which is ideal because it has never been consumed like other materials, can be installed in parallel to support many usages, and indeed it is always available for reuse. The value of data is often neglected and increases with time the business effectively uses it, often to support secondary use that is not anticipated when datais first collected. Even superficial or false data (such as data with typographical errors) may be harvested to make a profit. Google develops commercial spelling and sound checks that are a powerful introduction to the software by learning from data that is wrong about common mistakes people make when they type or speak. Data can also be recombined with other data to produce added value [18].

According to Pratama [3] Big Data is a technology related to data and used in the process of integration and migration of information technology-based systems. According to Oracle in the White paper entitled Oracle: Big Data for Enterprise, it is stated that Big Data is large and very large data collection originating fromv arious sources of enterprise enterprise data (CRM, ERP, Web, electronic transactions), scanning data (sensor data), computational data (generating machine data) and data -data froms ocial media and social networking (social data) which have four main characteristics, commonly referred to as $5 \mathrm{~V}$. Includes volume (capacity), variety (variety), velocity (data streaming speed) and veracity (data value).

In the world of information technology, the role of Big Data, in general, is very much. In the enterprise (organization in the form of a company) Big Data helps in business analys is, decision making, product innovation, knowing market needs (consumers), which are related to the continuity of the company's business and competition with other competitors [3]. There are six functions of Big Data [19]. The first is Tracking, Tracking or tracking social media created to involve viewers is the emergence of the use of social analysis. The second is Intelligence, Online social intelligence is more than just a series of advanced artificial algorithms that run on different computing platforms. The third is Metadata, Metadata is defined as data about the contents of existing data or in other words, information about data in a data environment. The fourth is Surveillance, Surveillance is the processing of personal data for certain purposes. The fifth is Extracting, at this stage, the data collection results can be extracted for further processing including analys is, operation al reporting, data warehouse integration and visualization purposes. The last is Data Mining, Data mining is an analysis process to dig up hidden information by using statistics and artificial intelligence in a very large database, so that a pattern of previously unknown data is found, and the pattern is represented by computer graphics to be easily understood.

\subsection{Fiture of Big Data ( Bit Wafel)}

In this study we use Big Data tools with its name Bit Wafl. Bit Wafl is like mostly others Big Data. General Big Data Technology Features consists of Predictive analytics, Social Media Analytic, Conten Base Analytics, Text Analytics, Audio Analytics and Video Analytics. 


\subsection{Theoretical Framework}

This study review the current political campaign using analog and digital media, political campaigns through digital media such as social media and online media have generated digital track records for us ers, and become part of Big Data. This is reflected in the big data study in the 2012 presidential election in the United States, where big data has been placed as a storage media and media channel for its users because it requires an analysis that is able to recommend strategies and politicaldecisions for future political campaigns. Based on the description of the role and function of the Big Data above, the authors limit the role and function of the Big Data in a Political Campaign by taking the second phase of the DKI Jakarta gubernatorial election campaign case study (March-April 2017). Here is framework of theoretical:

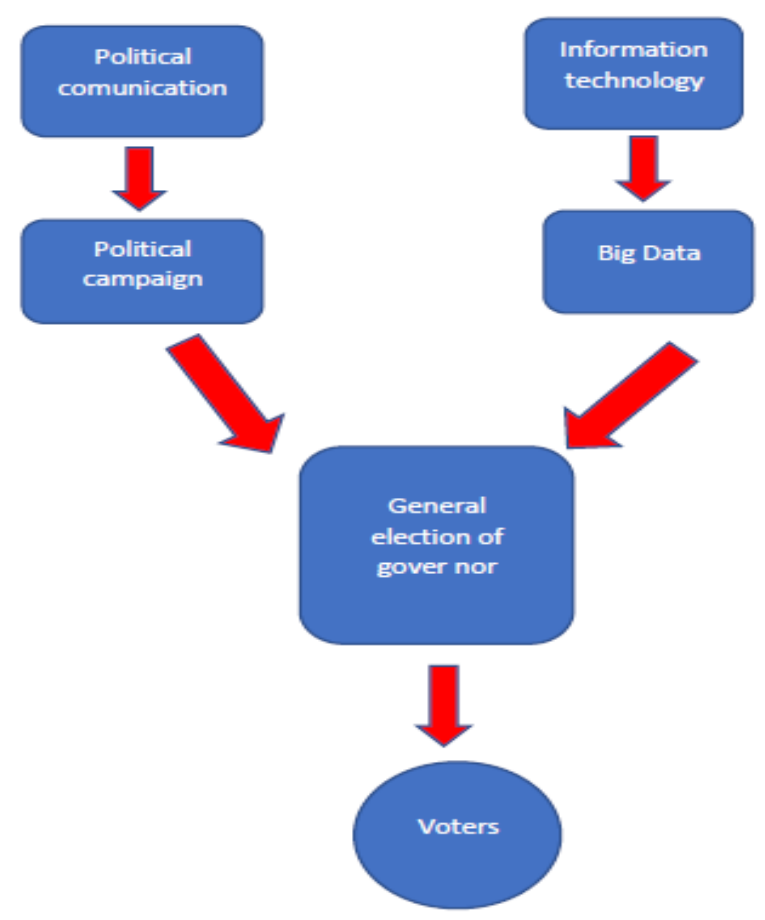

Fig. 1. Theoretical framework of research

\section{Research Methods}

This study uses Mixed Method. Quantitative data analysis technique is done descriptively that is describing the results of data obtained from the computed BitWafl computing engine. While in qualitative research, data analysis techniques in this study use narrative and thematic analys is. The source of data is primary and secondary data. Primary data obtained by interviewing informants and seceondary data obtained by Bit Wafl application and internet. The results of data analy sis will be explained based on the features or tools available on BitW afl with the parameters used respectively. Data analysis techniques are narrative, combining secondary data and data obtained frominterv iews. In qualitative research the data confirmation is done by the process of triangulation The process of triangulation in 
qualitative research in this thesis is done by collecting data through various sources, like internet, media and social media and the results of data withdrawal with BitWafl so that the results of interviews with informants who are part Anis Sandi's success team can be analyzed completely.

\section{Result and Discussion}

According to the data period drawn from March to April 2017, the number of talks that occurred related to the topic of Anies-Sandy in various types of media had a greater number of 428 talks per posts, but the intensity of the talks from time to time was uneven. with confirmation of the informant's interview results. Further data analysis about social media, where Twitter social media is the most widely used media in discussions related to Anies-Sandy topics with a percentage of $84 \%$, followed by online news by $12.3 \%$. Based on the results of the interview informants this data corresponds to $90 \%$. Then for content analysis, it can be seen that the sentiment about Anies Sandy is more positive. Likewise, based on text analys is data. Furthermore, for video analy sis data, generally the res ults of influencers posting from the website bolalob.comreach 329 thousand reaches and engagement 5000. Based on information from informants, this is since in the Anis Sandy team, more approached young people with topics which are sports especially soccer. The results of data drawn with the Big Data Bit Wafl application after being confirmed with the res ults of interviewees and their data have 80 percent valid. thus the results of this study are consistent with previous studies conducted by Nickers on and Rogers [6] and also Burt [7] and Bennet [8]. Where they found that the use of big data technology in the campaign was very helpful. Even President Obama gained his fortune for successfully utilizing Big Data technology to influence voters .

\section{Conclusion}

Based on the results of this study and also previous research on the role of Big Data in campaigns both campaigns for political and corporate purposes, it can be said that big data technology has a large role and benefits in the campaign. This is certainly depend on how to design the right message format in campaigning as part of the concept of political communication. Thus the authors recommend the use of Big Data technology for communication practitioners. While academically it is necessary to continue to study and develop the concept of political communication with other data methodologies and analyzes .

\section{References}

[1] L. L. Kaid, Handbook of Political Communication Research. New Jersey: Lawrene Erlbaum Associates, 2015.

[2] S. Kemp, "Digital 2019: Global Internet Use Accelerates 2019," https://wearesocial.com/blog/2019/01/digital-2019-global-internet-use-accelerates\#2019, 2019. [Online]. Available: https://wearesocial.com/blog/2019/01/digital-2019-global-internet-useaccelerates\#2019. [Accessed: 20-Nov-2019].

[3] I. P. A. E. Pratama, Integrasi dan Migrasi Sistem. Bandung: Informatika, 2016.

[4] S. Sudhahar, G. A. Veltri, and N. Cristianini, "Automated analysis of the US presidential elections using Big Data and network analysis," in Sage Publication, 2015.

[5] L. I. Conway, L. Gornick, C. Burfeind, and et.al., "Does Complex Or Simple Rhetoric Win Elections? An Integrative Complexity Analysis Of Us Presidential Campaigns," Polit. Psychol., vol. 33, no. 5, pp. 599-618, 2012.

[6] W. N. David and T. Rogers, "Political Campaigns and Big Data," J. Econ. Perspect., vol. 28, 
no. 2, pp. 51-74, 2014.

[7] G. Burt, "My Time at "Obama for America: Tech in Motion," http://www.techinmotionevents.com/blog /post/2013/08/27/my-time-at-obama-foramerica.2013, 2013. [Online]. Available: http://www.techinmotionevents.com/blog /post/2013/08/27/my-time-at-obama-for-america.2013.

[8] C. J. Bennet, Big Data and Voter Surveillance Department of Political Science. Canada: University of Victoria, 2016.

[9] N. Sari, "Survey SMRC 58 Persen Warga DKI Ingin Ahok Kembali Jadi Gubernur 2016," http://megapolitan.kompas.com/read/2016/07/21/20163011/survei.smrc.58.persen.warga.dki.in gin.ahok.kembali.jadi.gubernur.2016, $2016 . \quad$ [Online]. Available: http://megapolitan.kompas.com/read/2016/07/21/20163011/survei.smrc.58.persen.warga.dki.ing in.ahok.kembali.jadi.gubernur.2016.

[10] Anonim, "Survei SMRC: Elektabilitas Ahok-Djarot Kian Meningkat 2017," http://pilkada.liputan6.com/read/2920142/survei-smrc-elektabilitas-ahok-djarot-kianmeningkat.2017, 2017. .

[11] D. McQuil, Teori Komunikasi Massa. Jakarta: Salemba Humanika, 2010.

[12] D. Nimmo, Komunikasi Politik: Komunikator, Pesan dan Media. Bandung: Rosda, 2011.

[13] M. Schudson, "Why Conversation is Not the Soul of Democracy: Critical Studies in Mass Communication," in Modern Social Imaginaries, England: Duke, 1997, pp. 297-309.

[14] E. M. Rogers and J. D. Storey, "Communication Campaigns," in Handbook of Communication Science, C. R. Berger and S. H. Chaffee, Eds. New Burry: Sage Publications, Inc., 1987, pp. $817-846$.

[15] S. Judith and R. V. Friedenberg, Political Campaign Communication: Principles and Practices. Westport: Praeger Publisher, 2000.

[16] C. Eaton and et.al., Understanding Big Data: Analytics For Enterprise Class Hadoop Understanding Big Data. 2011.

[17] E. Dumbill, Big Data Now Current Perspective. Sebastopol: O’Reilly Media, Inc., 2012.

[18] V. Mayer-Schonberger and K. Cukier, Big Data: A Revolution That Will Transform How We Live, Work and Think. Canada: Eamon Dolan/Houghton Mifflin Harcourt, 2013.

[19] K. Krishnan, Data Warehousing in the age of Big Data. Waltham USA: Wyman Street, 2013. 